\title{
Effect of pig genotypes from Slovak and Polish breeds on meat quality
}

\author{
Ondrej Debrecéni ${ }^{1}$, Petra Lípová ${ }^{1}$, Ondřej Bučko $^{1}$, Aleksandra Cebulska ${ }^{2}$, and Wojciech Kapelánski ${ }^{2}$ \\ ${ }^{1}$ Department of Animal Husbandry, Slovak University of Agriculture, 94976 Nitra, Slovakia \\ ${ }^{2}$ Department of Pig Breeding, University of Technology and Life Sciences, 85084 Bydgoszcz, Poland
}

Correspondence: Petra Lípová (petalipova@gmail.com)

Received: 15 June 2017 - Revised: 4 January 2018 - Accepted: 11 January 2018 - Published: 27 February 2018

\begin{abstract}
Nowadays, meat and meat products from indigenous pig breeds are desired by consumers for their high sensory quality. For that reason, the trend to use indigenous pig breeds for production of these products has widened. The aim of this study was to compare physical and chemical parameters of Musculus longissimus dorsi (MLD) as well as content of cholesterol and fatty acid profiles among Mangalitsa, the crossbreed Mangalitsa $\times$ Duroc, and pig meat breed Slovak Large White with Polish indigenous breeds Pulawska and Zlotnicka spotted. In the study, 48 pigs were used. The pigs were divided into 5 groups of different genotypes: Mangalitsa breed $(n=9)$, the crossbreed Mangalitsa $\times$ Duroc $(n=9)$, Slovak Large White - SLW $(n=10)$, Zlotnicka spotted $(n=10)$ and Pulawska $(n=10)$. The pigs were reared under intensive conditions, and they were fed by an ad libitum system with complete feed mixtures. The fattening period lasted from 30 to $100 \mathrm{~kg}$ of live weight. The SLW had the highest average daily gain with the lowest feed intake compared to Mangalitsa, the crossbreed $\mathrm{Ma} \times \mathrm{Du}$ and Polish indigenous breeds $(P<0.001)$. SLW had the highest meat content in the carcass while Mangalitsa had the lowest $(P<0.001)$. Mangalitsa and their crossbreed $\mathrm{Ma} \times \mathrm{Du}$ had the highest fat content in the carcass, but the SLW and Polish indigenous pig breeds had the lowest fat content in the carcass $(P<0.001)$. As regards the physical properties of MLD, the Polish indigenous pig breeds achieved the highest values of $\mathrm{pH}_{45} \mathrm{~min}$ post mortem, the lowest drip loss values, the lowest colour values of CIE $\mathrm{L}^{*}$ and the highest values of CIE $\mathrm{b}^{*}$ compared to other genotypes in the experiment $(P<0.001)$. However the meat of crossbreed Ma $\times$ Du had pale, soft and exudative (PSE)-like conditions due to the low $\mathrm{pH}_{45}$ min post mortem, the high values of drip loss and CIE L*. The crossbreed $\mathrm{Ma} \times \mathrm{Du}$ and Polish indigenous pig breeds had the highest content of intramuscular fat in MLD compared to Mangalitsa and SLW $(P<0.001)$. The cholesterol content in MLD was the highest in Polish pig breeds and the lowest in SLW $(P<0.001)$. Regarding the fatty acid content in the meat, intramuscular fat (IMF) from Zlotnicka spotted was significantly the most polyunsaturated with the highest percentages of C18:2n-6, C20:5n-3 and C22:6n-3, and it had the lowest percentages of monounsaturated fatty acids (MUFAs) as well as contents of C18:1 cis-9 and C18:1trans-11 compared to other genotypes $(P<0.001)$. IMF from Slovak Large White was the most saturated and monounsaturated with the highest content of C18:1 cis-9, and it has the lowest percentages of polyunsaturated fatty acids (PUFAs) in IMF compared to genotypes in the study $(P<0.001)$. From the results, it follows that the Polish indigenous pig breeds are more suitable for the breeding and production of special meat products due to acceptable fattening and carcass parameters as well as the meat quality. As regards fatty acid composition of meat, the direct influence between fatty acid composition in diet and in Musculus longissimus dorsi was not determined. However, the genotypes have a significant impact on fatty acid profiles in MLD.
\end{abstract}


Copyright statement. The experiment is an original work and has not been published before. The work does not contain content that is unlawful and/or abusive, and it does not constitute a breach of confidence or of commitment given in secrecy. We agree with terms of the licence and copyright agreement.

\section{Introduction}

In recent years, consumers and the meat industry have emphasized the descending quality of pig meat offered - such as the high frequency of pale, soft and exudative (PSE) fault express by high drip loss and low water-holding capacity, unacceptable taste of pork, and low content of intramuscular fat (Florowski et al., 2006). Indigenous pig breeds such as Mangalitsa, Zlotnicka spotted and Pulawska are less suitable than other pig meat breeds due to low meat content in the carcass, but the slaughter value of indigenous pigs can be improved by crossing them with high-meat-quality breeds. Meat producers believed that production of fermented meat products of high sensory value requires special raw material obtained from pigs of high live weight, supplying meat of $\mathrm{pH}$ 5.6-5.8 $24 \mathrm{~h}$ and containing approximately $3.5 \%$ of intramuscular fat (Grześkowiak et al., 2009). The meat of Mangalitsa belongs to the group of fat, rich meat, which is darker, more succulent and softer with higher tenderness than the meat from pig meat breeds (Parunović et al., 2013). The Mangalitsa meat and fat do not contain a lower level of cholesterol than other breeds of pigs. The cholesterol is the natural component of each cell, being the base for vitamin $\mathrm{D}$ synthesis and steroid hormones (Cordis et al., 2015).

Content of fatty acids in meat has the key elements that control meat quality and an important role in the nutritional feeding values of the meat (Habeanu et al., 2014). Oils and fats are important in human nutrition, but excessive or insufficient intake of fat can have adverse effects on human health. In human nutrition, $15-30 \%$ of energy should be derived from fat. Less than $10 \%$ should be received from saturated fatty acids (SFAs), although their higher level increases the cholesterol content in the blood (Petrović et al., 2014), various cancers and especially coronary heart diseases (Wood et al., 2003). The polyunsaturated fatty acid (PUFA) content should be $6-10 \%$ due to the requirement for essential fatty acids (Petrović et al., 2014). The content of PUFA was greater than $60 \%$ in the fat of Mangalitsa breed, and they almost reached this percentage in the crosses (Parunović et al., 2013). The PUFA / SFA ratios as well as $n-6 / n-3$ PUFA ratios have become the most important parameters in the evaluating the nutritional value and healthiness of meat (Parunović et al., 2012). According to Szabó et al. (2010) the content of PUFA and monounsaturated fatty acids (MUFAs) in adipose tissue of Mangalitsa was higher than for Large White (72.9\% vs. $63.8 \%$ ). On the contrary, the content of SFA was higher in adipose tissue of Large White than in Mangalitsa (36.2\% vs. $27.1 \%)$.
Table 1. The composition of complete feed mixture in Slovakia.

\begin{tabular}{lr}
\hline Ingredients & $\%$ \\
\hline Corn & 50 \\
Barley & 10 \\
Wheat & 10 \\
Soybean meal & 10 \\
Linseed meal & 10 \\
Granulated alfalfa & 7 \\
Mineral and vitamin supplement* & 3 \\
\hline
\end{tabular}

* Retinol $40 \mathrm{mg}$, cholecalciferol $3750 \mu \mathrm{g}, \alpha$-tocopherol $400 \mathrm{mg}$, riboflavin $80 \mathrm{mg}$, pyridoxine $30 \mathrm{mg}$, cyanocobalamin $1000 \mu \mathrm{g}$, niacinamide $300 \mathrm{mg}$, folic acid $2 \mathrm{mg}$, pantothenic acid $300 \mathrm{mg}$, choline chloride $4000 \mathrm{mg}$, Cu $600 \mathrm{mg}$, Fe $3400 \mathrm{mg}$, Zn 1000 mg, Mn $1000 \mathrm{mg}$, I $30 \mathrm{mg}$, Se $8 \mathrm{mg}$.

The aim of this study was to compare physical and chemical parameters of Musculus longissimus dorsi (MLD) as well as content of cholesterol and fatty acid content among Mangalitsa, crossbreeds Mangalitsa $\times$ Duroc, pig meat breed Slovak Large White with Polish indigenous breeds Pulawska and Zlotnicka spotted.

\section{Material and methods}

The experimental material consisted of 48 pigs, divided into 5 groups of different genotypes: Mangalitsa breed $(n=9)$, crossbreed Mangalitsa $\times$ Duroc $(n=9)$, Slovak Large White $(n=10)$, Zlotnicka spotted $(n=10)$ and Pulawska $(n=10)$. The experiments with Mangalitsa breed, crossbreed Mangalitsa $\times$ Duroc $(\mathrm{Ma} \times \mathrm{Du})$ and pig meat breed Slovak Large White (SLW) were realized at the Experimental Centre of Farm Animal near the Department of Animal Husbandry at the Slovak University of Agriculture (SUA) in Nitra.

\subsection{Feeding and rearing conditions of pigs}

Pigs were reared under intensive conditions. The pen consisted of concrete floor with bedding straw. Pigs were fed by complete feed mixture for fatteners. The composition of complete feed mixture for pigs fattened in Slovakia is presented in Table 1. The pigs received drinking water and complete feed mixture for fatteners via an ad libitum system. The Zlotnicka spotted and Pulawska were reared under intensive conditions at the Rolmies farm in Labiszyn, Poland. Pigs had the same rearing conditions as pigs in Slovakia, and they were fed by complete feed mixture for fatteners via an ad libitum system. The composition of complete feed mixtures for pigs reared in Poland is presented in Table 2. Proximate composition and fatty acid profiles of pig diets are shown in Table 3. 
Table 2. Composition of complete feed mixture in Poland.

\begin{tabular}{lr}
\hline Ingredients & $\%$ \\
\hline Barley & 60 \\
Wheat & 20 \\
Post-extraction soybean & 12 \\
Pea & 5 \\
Mineral and vitamin supplement & 3 \\
\hline
\end{tabular}

Retinol $42 \mathrm{mg}$, cholecalciferol $3750 \mu \mathrm{g}, \alpha$-tocopherol $500 \mathrm{mg}$, riboflavin $80 \mathrm{mg}$, pyridoxine $30 \mathrm{mg}$, cyanocobalamin $1000 \mu \mathrm{g}$, niacinamide $300 \mathrm{mg}$, folic acid $2 \mathrm{mg}$, pantothenic acid $300 \mathrm{mg}$, choline chloride $4000 \mathrm{mg}$, Cu $550 \mathrm{mg}$, Fe $3400 \mathrm{mg}$, Zn $1000 \mathrm{mg}$, Mn 1000 mg, I 30,mg, Se 8 mg.

\subsection{Sampling}

Fattening period lasted from 30 to $100 \mathrm{~kg}$ of live weight. Pigs were weighed each week. Pigs were electrically stunned and slaughtered according to government regulations "about the protection of animals during the slaughter" (GR SR 432/2012). The dissection of carcasses was done according to standard practices of station of fattening and slaughter values. The average of back-fat thickness was calculated from three measurements: on the second thoracic vertebra, on the last thoracic vertebra and on the first sacral vertebra. The loin cross-section area was measured behind the last rib. The loin eye area was measured by planimetering. Measurements were taken on right half of carcasses, and the physicochemical parameters were carried out on $500 \mathrm{~g}$ of Musculus longissimus dorsi (MLD).

\subsection{Analysis of physical parameters}

The actual acidity $\left(\log \operatorname{molc}^{(H+)}\right)$ in the MLD (measured between third and fourth lumbar vertebra) $\mathrm{pH}$ values $45 \mathrm{~min}\left(\mathrm{pH}_{45}\right)$ and $\mathrm{pH}$ values $24 \mathrm{~h}\left(\mathrm{pH}_{24}\right)$ post mortem were measured by $\mathrm{pH}$ meter Hanna HI99161. Drip loss (\%) was determined as the weight loss of MLD between 24 and $48 \mathrm{~h}$ of storage, placed in vacuum plastic bags and hung in the refrigerator at $4{ }^{\circ} \mathrm{C}$ according to Honikel (1998).

Meat colour was measured in MLD at $24 \mathrm{~h}$ post mortem using a Minolta colorimeter (Chroma Meter CR-310, Minolta Camera C., Osaka, Japan). Commission Internationale de l'Eclairage (1975) determined the following colour coordinates: L* (lightness, white \pm black), a* (redness, red \pm green) and $b^{*}$ (yellowness, yellow \pm blue). These values were recorded from the average of three random readings across each muscle surface.

Warner-Bratzler shear force of meat was measured using a Warner-Bratzler shear device (Chatillon, USA), in accordance with Goodson et al. (2002). The MLD samples were warmed in a water bath at an internal temperature of $70^{\circ} \mathrm{C}$ for $30 \mathrm{~min}$. Then, the samples were wrapped in plastic film and stored in a cooler overnight before coring. The cores were sheared perpendicular to the muscle fibres' orientation.
Table 3. Proximate composition and fatty acid profiles (\%) of the pig diets.

\begin{tabular}{|c|c|c|}
\hline & Diet SK* & Diet PL* \\
\hline \multicolumn{3}{|c|}{ Proximate composition } \\
\hline $\mathrm{MJ} \mathrm{kg}^{-1}$ & 13.5 & 12.6 \\
\hline Crude protein $(\%)$ & 13.8 & 15.6 \\
\hline Crude fat $(\%)$ & 5.2 & 2.5 \\
\hline Crude fibre $(\%)$ & 7.4 & 4.8 \\
\hline Lysine (\%) & 0.8 & 0.8 \\
\hline \multicolumn{3}{|c|}{ Fatty acid composition (\%) } \\
\hline C:16 (palmitic) & 8.7 & 18.8 \\
\hline C18:0 (stearic) & 2.6 & 4.1 \\
\hline C18:1cis n9 (oleic) & 18.3 & 14.1 \\
\hline C18:2n-6 (linoleic) & 63.9 & 53.3 \\
\hline C18:3n3 (alpha-linolenic) & 4.5 & 10.5 \\
\hline
\end{tabular}

Diet SK: diet for pigs reared in Slovakia, diet PL: diet for pigs reared in Poland.

\subsection{Analysis of basic chemical parameters}

Moisture content was determined by drying the sample of MLD in an oven at $105^{\circ} \mathrm{C}$ according to PNISO 1442:2000 (2000).

Protein content was determined by determination of nitrogen content according to Kjeldahl method PN-75/A04018 (1975).

Intramuscular fat content was determined using the Soxhlet method (PN-ISO 1444:2000, 2000).

The lipid fraction was isolated according to Folch et al. (1957) for the determination of cholesterol content from intramuscular fat in MLD. Cholesterol content was determined in accordance with standard ČSN 570185 (1985) using device Spekol 1300.

\subsection{Fatty acid content}

In order to determine the fatty acid profile, isolation of the lipid fraction was done via the method according to Folch et al. (1957). The preparation of fatty acids methyl esters was done according to Raes et al. (2001). Fatty acid methyl esters were analysed by gas chromatography (Agilent Technologies $6890 \mathrm{~N}$ ) according to ČSN ISO 5508 (1994). The gas chromatograph was equipped with DB-23 cyanopropylmethylpolysiloxane column $(60 \mathrm{~m} \times 0.25 \mathrm{~mm} \times 0.25 \mu \mathrm{m})$. The carrier gas was nitrogen (flow rate $0.8 \mathrm{~m} \mathrm{~min}^{-1}$ ), and the column temperature regime was as follows: $120^{\circ} \mathrm{C}$ for $6 \mathrm{~min}$, the temperature was increased to $170^{\circ} \mathrm{C}\left(15^{\circ} \mathrm{C} \mathrm{min}^{-1}\right)$ and then to $210^{\circ} \mathrm{C}\left(3^{\circ} \mathrm{C} \mathrm{min}^{-1}\right)$. The temperature was kept for $13.5 \mathrm{~min}$. After that the temperature was raised to $230^{\circ} \mathrm{C}$ $\left(40^{\circ} \mathrm{C} \mathrm{min}-1\right)$ and kept constant for $7 \mathrm{~min}$. The flame ionization detector temperature was $260^{\circ} \mathrm{C}$. Identification of fatty acids was made by comparing the following standards: 
Table 4. Fattening parameters of genotypes.

\begin{tabular}{|c|c|c|c|c|c|c|c|}
\hline Traits & $\begin{array}{l}\mathrm{Ma} \\
(n=9)\end{array}$ & $\begin{array}{l}\mathrm{Ma} \times \mathrm{Du} \\
(n=9)\end{array}$ & $\begin{array}{l}\mathrm{LW} \\
(n=10)\end{array}$ & $\begin{array}{l}\mathrm{ZS} \\
(n=10)\end{array}$ & $\begin{array}{l}\mathrm{PW} \\
(n=10)\end{array}$ & SEM & $p$ value \\
\hline Average daily gain $(\mathrm{g})$ & $614.1^{\mathrm{b}}$ & $805.0^{\mathrm{a}}$ & $834.4^{\mathrm{a}}$ & $616.8^{\mathrm{b}}$ & $637.9^{b}$ & 16.727 & $<0.001$ \\
\hline Feed intake (day $\mathrm{kg}^{-1}$ ) & $5.2^{\mathrm{a}}$ & $4.0^{\mathrm{b}}$ & $2.7^{\mathrm{d}}$ & $3.1^{\mathrm{c}}$ & $3.3^{\mathrm{c}}$ & 0.131 & $<0.001$ \\
\hline Feed consumption efficiency $\left(\mathrm{MJ} \mathrm{kg}^{-1}\right)$ & $69.6^{\mathrm{a}}$ & $54.0^{\mathrm{b}}$ & $36.4^{\mathrm{d}}$ & $43.0^{\mathrm{c}}$ & $41.5^{\mathrm{c}, \mathrm{d}}$ & 1.811 & $<0.001$ \\
\hline
\end{tabular}

Ma: Mangalitsa, Ma $\times$ Du: crossbred Mangalitsa $\times$ Duroc, LW: Large White, ZS: Zlotnicka spotted, Pw: Pulawska; ${ }^{a-d}$ Different letters in the same row indicate significant statistical differences (Tukey's test $P<0.05$ ), SEM: standard deviation of the mean.

Table 5. Production parameters of genotypes.

\begin{tabular}{lllllllr}
\hline Traits & $\begin{array}{l}\text { Ma } \\
(n=9)\end{array}$ & $\begin{array}{l}\text { Ma } \times \text { Du } \\
(n=9)\end{array}$ & $\begin{array}{l}\text { LW } \\
(n=10)\end{array}$ & $\begin{array}{l}\text { ZS } \\
(n=10)\end{array}$ & $\begin{array}{l}\text { Pw } \\
(n=10)\end{array}$ & SEM & $p$ value \\
\hline Slaughter weight $(\mathrm{kg})$ & $1007^{\mathrm{b}}$ & $108.4^{\mathrm{a}}$ & $100.9^{\mathrm{b}}$ & $103.3^{\mathrm{a}, \mathrm{b}}$ & $102.0^{\mathrm{b}}$ & 0.780 & 0.008 \\
Carcass length $(\mathrm{cm})$ & $71.6^{\mathrm{d}}$ & $80.9^{\mathrm{c}}$ & $97.7^{\mathrm{a}}$ & $86.0^{\mathrm{b}}$ & $83.1^{\mathrm{b}, \mathrm{c}}$ & 1.309 & $<0.001$ \\
Hot carcass weight $(\mathrm{kg})$ & 81.1 & $84.1^{\mathrm{b}}$ & 80.8 & 82.7 & 81.9 & 0.595 & 0.443 \\
Slaughter yield $(\%)$ & $80.5^{\mathrm{a}}$ & $77.5^{\mathrm{b}}$ & $80.1^{\mathrm{a}}$ & $80.0^{\mathrm{a}}$ & $80.3^{\mathrm{a}}$ & 0.230 & $<0.001$ \\
Cold carcass weight $(\mathrm{kg})$ & 79.9 & 82.1 & 79.1 & 81.4 & 80.3 & 0.564 & 0.407 \\
Chilling loss $(\%)$ & 1.1 & 1.2 & 1 & $0.8^{2}$ & 0.9 & 0.056 & 0.120 \\
Loin eye area (mm $\left.{ }^{2}\right)$ & $26.1^{\mathrm{c}}$ & $40.0^{\mathrm{b}}$ & $48.0^{\mathrm{a}}$ & $37.8^{\mathrm{b}}$ & $37.9^{\mathrm{b}}$ & 1.217 & $<0.001$ \\
Back-fat thickness $(\mathrm{cm})$ & $5.7^{\mathrm{a}}$ & $4.1^{\mathrm{b}}$ & $1.7^{\mathrm{d}}$ & $2.9^{\mathrm{c}}$ & $3.1^{\mathrm{c}}$ & 0.211 & $<0.001$ \\
\hline
\end{tabular}

Ma: Mangalitsa, Ma $\times$ Du: crossbred Mangalitsa $\times$ Duroc, LW: Large White, ZS: Zlotnicka spotted, Pw: Pulawska; ${ }^{\text {a-d }}$ different letters in the same row indicate significant statistical differences (Tukey's test $P<0.05$ ), SEM: standard deviation of the mean.

37 Component FAME Mix, PUFA No. 1, No. PUFA 2, No. PUFA 3, Sigma-Aldrich.

\subsection{Statistical analysis}

The effects of genotypes on studied parameters were analysed by one-way analysis of variance (ANOVA) using Statistic Analysis System (SAS) package (SAS 9.2. using of application Enterprise guide 5.1, SAS, 2012). Tables show means and standard deviation of the mean (SEM). When ANOVA was significant the means were compared using Tukey's test.

\section{Results and discussion}

Means and SEM of fattening and production parameters from genotypes are shown in Tables 4 and 5 . The average daily gain was significantly the highest in Slovak Large White and the lowest in Mangalitsa breed compared to other genotypes $(P<0.001)$. The Mangalitsa breed had the highest feed intake per $1 \mathrm{~kg}$ gain as well as feed consumption efficiency per $1 \mathrm{~kg}$ gain, and Slovak Large White had the lowest $(P<0.001)$. The other genotypes achieved middle values, where differences were significant $(P<0.001)$ between crossbreed $\mathrm{Ma} \times \mathrm{Du}$ and Polish indigenous breeds. These results are in agreement with findings of Pârvu et al. (2011), where Large White had higher average daily gain and lower feed intake as well as feed consumption efficiency than the Mangalitsa breed. In a similar study Szulc et al. (2012a) de- scribed that Zlotnicka spotted had the lowest average daily gain than crossbreeds Zlotnicka spotted $\times$ Duroc. Tyra and Žak (2010) compared Polish Large White and Pulawska breed, where Polish Large White achieved higher average daily gain than Pulawska breed, but in the current study the values were lower. Results confirmed that pig meat breeds reached higher average daily gain and lower feed intake per $1 \mathrm{~kg}$ gain than indigenous breeds and crossbreeds $\mathrm{Ma} \times \mathrm{Du}$, but Polish indigenous breed had more economically acceptable fattening parameters than Mangalitsa breed and their crossbreed.

The slaughter yield of carcass was significantly the lowest in crossbreed $\mathrm{Ma} \times \mathrm{Du}$ compared with other genotypes in the assay $(P<0.001)$. The value of loin eye area MLD was the highest in SLW and the lowest in Mangalitsa breed $(P<0.05)$. The Polish indigenous breeds reached middle values, but lower than crossbreed $\mathrm{Ma} \times \mathrm{Du}$. The differences were not significant. Mangalitsa breed had the highest backfat thickness and the lowest SLW $(P<0.001)$. Polish indigenous breeds achieved middle values, but crossbreed $\mathrm{Ma} \times \mathrm{Du}$ had higher back-fat thickness $(P<0.001)$. These results are in agreement with findings reported by Grzeškowiak et al. (2009), Jankowiak et al. (2009) and Bocian et al. (2012). Wojtyšiak and Poltowicz (2014) showed that Pulawska had lower value of loin eye area, but higher back-fat thickness than their crossbreeds. The results confirm that indigenous breeds had lower lean meat contents and higher fat content in carcass. Polish indigenous breed had higher lean meat con- 
Table 6. The physical properties in Musculus longissimus dorsi of genotypes.

\begin{tabular}{|c|c|c|c|c|c|c|c|}
\hline Traits & $\begin{array}{l}\text { Ma } \\
(n=9)\end{array}$ & $\begin{array}{l}\mathrm{Ma} \times \mathrm{Du} \\
(n=9)\end{array}$ & $\begin{array}{l}\mathrm{LW} \\
(n=10)\end{array}$ & $\begin{array}{l}\mathrm{ZS} \\
(n=10)\end{array}$ & $\begin{array}{l}\mathrm{Pw} \\
(n=10)\end{array}$ & SEM & $p$ value \\
\hline $\mathrm{pH}_{45 \min }\left(\log\right.$ molc $\left.^{-1}\right)$ & $6.1^{\mathrm{b}}$ & $5.9^{\mathrm{b}}$ & $6.1^{\mathrm{b}}$ & $6.4^{\mathrm{a}}$ & $6.5^{\mathrm{a}}$ & 0.054 & $<0.001$ \\
\hline $\mathrm{pH}_{24 \mathrm{~h}}\left(\log \mathrm{molc}^{-1}\right)$ & $5.6^{\mathrm{a}}$ & $5.6^{\mathrm{a}}$ & $5.5^{\mathrm{b}}$ & $5.6^{\mathrm{a}}$ & $5.6^{\mathrm{a}}$ & 0.019 & 0.001 \\
\hline Drip loss $24 \mathrm{~h}(\%)$ & $8.8^{\mathrm{a}}$ & $9.0^{\mathrm{a}}$ & $7.3^{\mathrm{a}, \mathrm{b}}$ & $2.9^{\mathrm{c}}$ & $4.7^{\mathrm{b}, \mathrm{c}}$ & 0.481 & $<0.001$ \\
\hline Colour $_{24 h}$ CIE L* & $53.0^{\mathrm{c}}$ & $63.6^{\mathrm{a}}$ & $57.4^{\mathrm{b}}$ & $49.2^{\mathrm{d}}$ & $52.1^{\mathrm{c}, \mathrm{d}}$ & 0.809 & $<0.001$ \\
\hline Colour $_{24 \mathrm{~h}} \mathrm{CIE} \mathrm{a}^{*}$ & 2.7 & 2.9 & 0.9 & 2.7 & 3.1 & 1.082 & 0.095 \\
\hline Colour $_{24 \mathrm{~h}}$ CIE b* & $10.4^{\mathrm{d}}$ & $13.1^{\mathrm{c}}$ & $10.6^{\mathrm{d}}$ & $17.8^{\mathrm{a}}$ & $16.1^{\mathrm{b}}$ & 0.622 & $<0.001$ \\
\hline Shear force $\left(\mathrm{kg} \mathrm{cm}^{-2}\right)$ & $2.3^{\mathrm{b}}$ & $2.1^{\mathrm{c}}$ & $4.3^{\mathrm{a}}$ & $4.2^{\mathrm{a}}$ & $3.7^{\mathrm{a}}$ & 2.652 & $<0.001$ \\
\hline
\end{tabular}

Ma: Mangalitsa, Ma $\times$ Du: crossbred Mangalitsa $\times$ Duroc, LW: Large White, ZS: Zlotnicka spotted, Pw: Pulawska; ${ }^{a-d}$ different letters in the same row indicate significant statistical differences (Tukey's test $P<0.05$ ), SEM: standard deviation of the mean.

tent and lower fat content in carcass than with Mangalitsa breed, but crossbreed $\mathrm{Ma} \times \mathrm{Du}$ had higher lean meat content and also higher fat content in carcass.

The results for the physical properties of Musculus longissimus dorsi (MLD) are presented in Table 6. The $\mathrm{pH}_{45 \text { min }}$ was higher in Polish indigenous breeds than in Mangalitsa and their crossbreed $(P<0.001)$. The ultimate $\mathrm{pH}_{24 \mathrm{~h}}$ decreased after $24 \mathrm{~h}$, and it was the lowest in SLW than in other genotypes in the trial $(P<0.001)$. The MLD from crossbreed $\mathrm{Ma} \times \mathrm{Du}$ and Mangalitsa breed tended to have a higher loss of water during refrigerated storage than Polish indigenous breeds $(P<0.001)$. The MLD from SLW achieved middle values. According to the study of Parunović et al. (2013), Mangalitsa breed had lower pH values in MLD than Landrace. Results of Polish indigenous breeds are in agreement with findings of other studies (Jankowiak et al., 2009; Wojtyšiak and Poltowicz, 2014).

An objective measure of Warner-Bratzler shear force is the force required to shear a piece of meat. The lowest value of Warner-Bratzler shear force of MLD was determined in crossbreed $\mathrm{Ma} \times \mathrm{Du}$ and the highest in MLD of SLW compared with other genotypes in the experiment $(P<0.001)$. The Mangalitsa breed and their crossbreed Ma $\times$ Du had significantly lower values of Warner-Bratzler shear force in meat than Polish indigenous breeds and pig meat breed SLW. Similarly, Stanišić et al. (2015) described that meat from Mangalitsa breed had lower values of Warner-Bratzler shear force than meat from Landrace, but in our study lower values was determined. In the study of Juárez et al. (2009) the texture parameters were higher in lines of Iberian pigs than in our experiment.

Regarding instrumental colour, the values of $\mathrm{L}^{*}$ (lightness) were the highest in MLD from crossbreeds $\mathrm{Ma} \times \mathrm{Du}$, which indicates that meat from crossbreed $\mathrm{Ma} \times \mathrm{Du}$ was paler than the other genotypes in the assay, but the CIE $\mathrm{L}^{*}$ value was the lowest in MLD from Zlotnicka spotted $(P<0.001)$. The index of red (CIE a*) was the highest in MLD from Pulawska and the lowest in MLD from SLW, although the differences were not statistically significant among genotypes. The value of CIE $b^{*}$ was the highest in MLD of Zlotnicka spotted, which is probably due to the higher share of intramuscular fat in MLD from Zlotnicka spotted. The lowest values of CIE $b^{*}$ were found in MLD from Mangalitsa and Large White compared to the MLD of other genotypes in the issue $(P<0.001)$. Similarly, Sirtori et al. (2011) indicated that crossbreeds of Nero Siciliano exhibited darker, redder meat with higher values of yellowness than meat from indigenous breed Nero Siciliano. Several lines of Iberian pigs and Chato Murciano exhibited lower values of lightness in meat but higher values of yellowness than our study. Values of redness are in accordance with results reported by several authors (Estévez et al., 2003; Juárez et al., 2009; Peinado et al., 2004). On the other hand, Poto et al. (2007) noted that indigenous breed Chato Murciano had higher values of colour parameters in meat than their crossbreeds. The results showed that Polish indigenous breed had lower values of drip loss in meat, darker and more yellow meat than genotypes from Slovakia. It can be concluded that the crossbreed $\mathrm{Ma} \times \mathrm{Du}$ had PSE meat due to low values of pH45 min, higher content of drip loss as well as higher content of colour value $\mathrm{L}^{*}$ than other genotypes in this issue.

Table 7 shows chemical properties and cholesterol content in MLD from genotypes. Polish indigenous breeds had significantly lower water content than genotypes from Slovakia $(P<0.001)$. The percentage of total protein was the highest in MLD from Zlotnicka spotted and the lowest in MLD from Pulawska $(P<0.001)$. The genotypes from Slovakia achieved middle values, where differences were not statistically significant. Intramuscular fat content in MLD was the highest in Pulawska and the lowest was in SLW $(P<0.001)$. This is in accordance with results of cholesterol content $(P<0.001)$. Similarly, Stanišić et al. $(2015,2016)$ observed lower water and protein contents but higher percentage of intramuscular fat in meat from Mangalitsa than Landrace. Sirtori et al. (2011) indicated that meat from indigenous breeds had lower water and protein contents but higher intramuscular fat content than their crossbreeds. Szulc et al. (2012b) showed higher percentage of water with higher intramuscular 
Table 7. The chemical properties in Musculus longissimus dorsi of genotypes.

\begin{tabular}{llllllll}
\hline Traits & $\begin{array}{l}\text { Ma } \\
(n=9)\end{array}$ & $\begin{array}{l}\text { Ma } \times \text { Du } \\
(n=9)\end{array}$ & $\begin{array}{l}\text { LW } \\
(n=10)\end{array}$ & $\begin{array}{l}\text { ZS } \\
(n=10)\end{array}$ & $\begin{array}{l}\text { Pw } \\
(n=10)\end{array}$ & SEM & $p$ value \\
\hline Total water $(\%)$ & $73.8^{\mathrm{a}}$ & $73.7^{\mathrm{a}}$ & $74.3^{\mathrm{a}}$ & $70.5^{\mathrm{b}}$ & $69.8^{\mathrm{b}}$ & 0.339 & $<0.001$ \\
Total protein $(\%)$ & $24.1^{\mathrm{a}, \mathrm{b}}$ & $23.7^{\mathrm{b}}$ & $23.7^{\mathrm{b}}$ & $25.2^{\mathrm{a}}$ & $23.3^{\mathrm{b}}$ & 0.271 & $<0.001$ \\
Intramuscular fat $(\%)$ & $1.9^{\mathrm{b}}$ & $2.4^{\mathrm{b}}$ & $1.2^{\mathrm{b}}$ & $2.6^{\mathrm{b}}$ & $5.5^{\mathrm{a}}$ & 0.161 & $<0.001$ \\
Cholesterol (mg $\left.100^{-1}\right)$ & $40.7^{\mathrm{b}}$ & $45.2^{\mathrm{b}}$ & $20.4^{\mathrm{c}}$ & $91.0^{\mathrm{a}}$ & $103.0^{\mathrm{a}}$ & 4.976 & $<0.001$ \\
\hline
\end{tabular}

Ma: Mangalitsa, Ma $\times$ Du: crossbred Mangalitsa $\times$ Duroc, LW: Large White, ZS: Zlotnicka spotted, Pw: Pulawska; ${ }^{\text {a-d }}$ different letters in the same row indicate significant statistical differences (Tukey's test $P<0.05$ ), SEM: standard deviation of the mean.

Table 8. Fatty acid composition of total intramuscular fat of Musculus longissimus dorsi from various genotypes.

\begin{tabular}{llllllll}
\hline Traits & $\begin{array}{l}\text { Ma } \\
(n=9)\end{array}$ & $\begin{array}{l}\text { Ma } \times \text { Du } \\
(n=9)\end{array}$ & $\begin{array}{l}\text { LW } \\
(n=10)\end{array}$ & $\begin{array}{l}\text { ZS } \\
(n=10)\end{array}$ & $\begin{array}{l}\text { Pw } \\
(n=10)\end{array}$ & SEM & $p$ value \\
\hline C16:0 & $24.50^{\mathrm{a}}$ & $24.37^{\mathrm{ab}}$ & $24.37^{\mathrm{ab}}$ & $23.56^{\mathrm{b}}$ & $24.27^{\mathrm{a}}$ & 0.108 & 0.035 \\
C18:0 & 11.17 & 11.18 & 11.28 & 11.01 & 11.74 & 0.105 & 0.225 \\
C18:1 cis-9 & $42.96^{\mathrm{a}}$ & $43.42^{\mathrm{a}}$ & $43.82^{\mathrm{a}}$ & $39.52^{\mathrm{b}}$ & $42.88^{\mathrm{a}}$ & 0.356 & $<0.001$ \\
C18:1trans-11 & $4.51^{\mathrm{a}}$ & $4.53^{\mathrm{a}}$ & $4.41^{\mathrm{a}}$ & $4.01^{\mathrm{b}}$ & $4.70^{\mathrm{a}}$ & 0.049 & $<0.001$ \\
C18:2n-6 & $9.16^{\mathrm{ab}}$ & $7.93^{\mathrm{bc}}$ & $8.87^{\mathrm{b}}$ & $10.85^{\mathrm{a}}$ & $6.16^{\mathrm{c}}$ & 0.308 & $<0.001$ \\
Conjugated linoleic acid & $0.132^{\mathrm{a}}$ & $0.119^{\mathrm{a}}$ & $0.132^{\mathrm{a}}$ & $0.087^{\mathrm{b}}$ & $0.061^{\mathrm{c}}$ & 0.005 & $<0.001$ \\
C18:3n-3 & $0.273^{\mathrm{c}}$ & $0.259^{\mathrm{c}}$ & $1.948^{\mathrm{a}}$ & $0.518^{\mathrm{b}}$ & $0.291^{\mathrm{c}}$ & 0.097 & $<0.001$ \\
C20:5n-3 & $0.103^{\mathrm{a}, \mathrm{b}}$ & $0.082^{\mathrm{c}}$ & $0.097^{\mathrm{b}}$ & $0.115^{\mathrm{a}}$ & $0.103^{a, b}$ & 0.002 & $<0.001$ \\
C22:5n-3 & $0.141^{\mathrm{c}}$ & $0.137^{\mathrm{c}}$ & $0.143^{\mathrm{c}}$ & $0.312^{\mathrm{b}}$ & $0.434^{\mathrm{a}}$ & 0.022 & $<0.001$ \\
C22:6n-3 & $0.042^{\mathrm{b}}$ & $0.041^{\mathrm{b}}$ & $0.044^{\mathrm{a}, \mathrm{b}}$ & $0.056^{\mathrm{a}}$ & $0.037^{\mathrm{b}}$ & 0.002 & $<0.001$ \\
SFA & $36.81^{\mathrm{b}}$ & $36.89^{\mathrm{b}}$ & $39.36^{\mathrm{a}}$ & $36.95^{\mathrm{b}}$ & $38.16^{\mathrm{a}, \mathrm{b}}$ & 0.241 & $<0.001$ \\
MUFA & $50.37^{\mathrm{b}, \mathrm{c}}$ & $51.24^{\mathrm{b}}$ & $54.51^{\mathrm{a}}$ & $47.70^{\mathrm{c}}$ & $52.45^{\mathrm{a}, \mathrm{b}}$ & 0.452 & $<0.001$ \\
PUFA & $12.15^{\mathrm{a}, \mathrm{b}}$ & $11.53^{\mathrm{b}, \mathrm{c}}$ & $8.18^{\mathrm{d}}$ & $15.09^{\mathrm{a}}$ & $9.23^{\mathrm{c}, \mathrm{d}}$ & 0.457 & $<0.001$ \\
PF / SF & $0.31^{\mathrm{b}}$ & $0.27^{\mathrm{c}}$ & $0.34^{\mathrm{ab}}$ & $0.39^{\mathrm{a}}$ & $0.23^{\mathrm{c}}$ & 0.011 & $<0.001$ \\
Omega 3 & $0.63^{\mathrm{b}}$ & $0.61^{\mathrm{b}}$ & $0.49^{\mathrm{b}}$ & $1.08^{\mathrm{a}}$ & $0.94^{\mathrm{a}}$ & 0.039 & $<0.001$ \\
Omega 6 & $10.96^{\mathrm{b}}$ & $9.89^{\mathrm{b}, \mathrm{c}}$ & $7.35^{\mathrm{c}}$ & $14.01^{\mathrm{a}}$ & $8.29^{\mathrm{c}}$ & 0.434 & $<0.001$ \\
$n-6 / n-3$ & $17.92^{\mathrm{a}}$ & $16.53^{\mathrm{a}}$ & $15.72^{\mathrm{a}, \mathrm{b}}$ & $12.94^{\mathrm{b}}$ & $8.89^{\mathrm{c}}$ & 0.567 & $<0.001$ \\
\hline
\end{tabular}

Ma: Mangalitsa, Ma $\times$ Du: crossbred Mangalitsa $\times$ Duroc, LW: Large White, ZS: Zlotnicka spotted, Pw: Pulawska; ${ }^{\text {a-d }}$ different letters in the same row indicate significant statistical differences (Tukey's test $P<0.05$ ), SEM: standard deviation of the mean.

fat content in MLD from Zlotnicka spotted than our results. Florowski et al. (2006) described that Zlotnicka spotted had lower water content and higher intramuscular fat content in MLD than in Pulawska, which diverges from our results. On the contrary, Pârvu et al. (2012) indicated that indigenous breed Mangalitsa reared in the alternative production system had lower cholesterol content than Large White. Similarly, Parunović et al. (2013) observed that meat from Mangalitsa breed had higher cholesterol content than meat from industrial pig breeds. The results confirmed that Polish indigenous breeds had lower water content in MLD but higher intramuscular fat and higher cholesterol contents in MLD than genotypes from Slovakia.

Major fatty acid composition in intramuscular fat in MLD from genotypes is presented in Table 8. Intramuscular fat (IMF) from Zlotnicka spotted was significantly the most polyunsaturated with the highest contents of $\mathrm{C} 18: 2 n$ 6, C20:5n-3 and C22:6n-3, and it has the lowest content of monounsaturated fatty acids (MUFAs) as well as contents of C18:1cis-9 and C18:1trans-11 compared to other genotypes $(P<0.001)$. IMF from SLW was the most saturated and monounsaturated with the highest content of C18:1 cis9 , and it has the lowest content of PUFA in IMF compared to genotypes in the study $(P<0.001)$. Mangalitsa, crossbreed $\mathrm{Ma} \times \mathrm{Du}$ and Pulawska achieved intermediate values of SFA, MUFA and PUFA without significant differences among them. The content of $n-3$ PUFA in IMF was higher in Zlotnicka spotted as well as Pulawska than genotypes from Slovakia $(P<0.001)$. Zlotnicka spotted had the highest content of $n-6$ PUFA in IMF and the lowest had Large White $(P<0.001)$. From the results, it follows that the diet did not influence fatty acid composition of IMF because there were significant differences among indigenous Polish breeds. However, genotype significantly affected fatty acid composition of IMF from MLD. 
According to Ramírez and Cava (2007) differences in fatty acid composition among genotypes can be caused by a different content of IMF. In our research, an association between IMF and fatty acid profile was not determined. Tomović et al. (2016) reported that pig meat Large White had more saturated and polyunsaturated IMF but less monounsaturated IMF than Mangalitsa breed. In our study lower values of PUFA in IMF were found than their results, and percentages of SFA and MUFA were in agreement with their results. In the study of Parunović et al. (2013), it was shown that pig meat breed Swedish Landrace had higher percentages of SFA and PUFA in IMF but lower percentage of MUFA than in Mangalitsa breed. The Swedish Landrace had higher total $n$-3 PUFA as well as total $n$-6 PUFA than Mangalitsa. According to Serra et al. (1998), the indigenous Iberian pigs achieved higher percentages of SFA and MUFA in meat, but it had a lower percentage of PUFA than pig meat breed Landrace. On the contrary, Renaudeau and Mourot (2007) indicated that indigenous pig breed Creole had in meat higher percentages of SFA and MUFA, but it had lower percentage of PUFA than Large White. They reported a higher percentage of SFA and lower percentage of MUFA than our results except regarding PUFA, which was in accordance with their results. Comparing our results with those in the study of Juaréz et al. (2009), the meat of Iberian pigs had lower content of MUFA and higher content of PUFA than in the meat of genotypes in our study. However the content of SFA was in agreement with our results.

As regards PF / SF ratio, the meat from Mangalitsa, SLW and Pulawska had a significantly higher ratio than meat from crossbreed $\mathrm{Ma} \times \mathrm{Du}$ and Zlotnicka spotted $(P<0.001)$, which is caused by the different content of C18:2n-6. According to Wood et al. (2003) the PF / SF ratio should be increased to above 0.4. Similarly, the British Committee on Medical Aspects of Food and Nutrition Policy (COMA) recommends a PUFA / SFA ratio higher than 0.45 (Petrović et al., 2014). In our study, the PUFA / SFA ratio was from 0.23 to 0.39 , which is not in accordance with the recommendations. Results in this study are in accordance with Parunović et al. (2013). However, Petrović et al. (2014) found lower values of $n-6 / n-3$ ratio in IMF between indigenous breeds Moravka and Mangalitsa than our results.

Nutritionists have also focused on the type of PUFA and the balance in the diet between $n-6$ PUFA and $n-3$ PUFA (Jeong et al., 2010). Pig muscle has a high ratio of $n-6 / n-3$ due to the high level of C18:2n-6, and it is difficult to reduce these values (Wood et al., 2008). In our study a high $n-6 / n-3$ ratio in the range of 8.89-17.92 was also found, where the IMF from meat of Mangalitsa had the highest $n$ $6 / n-3$ ratio and the lowest Pulawska $(P<0.001)$.

\section{Conclusions}

From the results, it follows that the Polish indigenous pig breeds are more suitable for the breeding and production of special meat products due to acceptable fattening and carcass parameters as well as the meat quality. As regards fatty acid composition of meat, direct influence was not determined between fatty acid composition in diet and in Musculus longissimus dorsi. However, the genotype has a significant impact on fatty acid profile in MLD. Because meat of indigenous pig breeds Mangalitsa, Zlotnicka spotted, Pulawska as well as crossbreeds Ma $\times$ Du had higher content of PUFA, but lower content of MUFA and SFA than pig meat breed Large White, it can be concluded that crossing pig meat breeds with the indigenous Mangalitsa breed did not improve fattening and carcass properties or meat quality compared to pig meat breed Slovak Large White and Polish indigenous pig breeds.

Data availability. Data are published only in this article.

Author contributions. OD and WK designed the experiments. $\mathrm{PL}$ and $\mathrm{OB}$ carried out the samples of pigs from Slovakia. AC carried out the samples of pigs from Poland. PL prepared the manuscript with contributions from all co-authors.

Competing interests. The authors declare that they have no conflict of interest.

Acknowledgements. This study was supported by the project "Biological and ethological effects on meat production with the required properties" of Agency of Ministry of Education, Science, Research and Sport of the Slovak Republic (VEGA) 1/0364/15.

Edited by: Steffen Maak

Reviewed by: Miroslav Rozkot and one anonymous referee

\section{References}

Bocian, M., Wojtysiak, D., Jankowiak, H., Cebulska, A., Kapelánski, W., and Migdal, W.: Carcass Meat Quality and Histochemical Traits of m. longissimus dorsi from Zlotnicka Spotted Pigs and Commercial Pigs, Folia Biologica, 60, 181-187, https://doi.org/10.3409/fb60_3-4.181-187, 2012.

Comission Internationale de 1'Eclairage: Comission Internationale de l'Eclairage 18th Session, September 1975, C.I.E publication, London, UK, p. 36, 1975.

Cordis, I., Mihaiu, M., Tăbăran, A., Mihaiu, R., Dan, S. D., Reget, O., Cordea, D. and Muresan, C.: Compositional Studies on Mangalitsa Meat Products for Public Consumption, Bull. UASCM Vet. Med., 72, 57-61, https://doi.org/10.15835/buasvmcnvm:10568, 2015.

ČSN 570185: Examination of meat, meat products and canned meat. Chemical and physical methods, The Czech Office for 
Standards, Metrology and Testing, Prague, Czech Republic, 1985.

ČSN ISO 5508: Animal and vegetable fats and oils. Analysis by gas chromatography of methyl esters of fatty acids, The Czech Office for Standards, Metrology and Testing, Prague, Czech Republic, 1994.

Estévez, M., Morcuende, D., and Cava, R.: Oxidative and colour changes in meat from three lines of free-range reared Iberian pigs slaughtered at $90 \mathrm{~kg}$ live weight and from industrial pig during refrigerated storage, Meat Science, 65, 1139-1146, https://doi.org/10.1016/s0309-1740(02)00343-1, 2003.

Florowski, T., Pisula, A., Adamczak, L., Buczyński, J. T., and Orzechowska, B.: Technological parameters of meat in pigs of two Polish local breeds-Zlotnicka Spotted and Pulawska, Anim. Sci. Pap. Rep., 24, 217-224, 2006.

Folch, J., Lees, M., and Stanley, S. G. H.: A simple method for the isolation and purification of total lipids from animal tissues, J. Biol. Chem., 226, 497-509, 1957.

Goodson, K. J., Morgan, W. W., Reagan, J. O., Gwartney, B. L., Couringtion, S. M., Wise, J. W., and Savell, J. W.: Beef customer satisfaction: factors affecting consumer evaluations of clod steaks, J. Anim. Sci., 80, 401-408, 2002.

Grześkowiak, E., Borys, A., Borzuta, K., Buczynski, J. T., and Lisiak, D.: Slaughter value, meat quality and backfat fatty acid profile in Zlotnicka White and Zlotnicka spotted fatteners, Anim. Sci. Pap. Rep., 27, 115-125, 2009.

Habeanu, M, Lefter, A., Gheroghe, A., Nagy, Al., Marin, D., and Ropota, M.: Effects of dietary flaxseed oil on the muscle fatty acid composition in Mangalitsa pigs in an extensive rearing system, S. Afr. J. Anim. Sci., 44, 240-244, https://doi.org/10.4314/sajas.v44i3.5, 2014.

Honikel, K. O.: Reference methods for the assessment of physical characteristics of meat, Meat Science, 49, 447-457, https://doi.org/10.1016/s0309-1740(98)00034-5, 1998.

Jankowiak, H., Kapelanski, W., Kwiatkowska, B. E., Biegniewska, M., and Cebulska, A.: Carcass and Meat Quality of Zlotnicka Spotted Pigs in Comparison to Polish Large White $\times$ Polish Landrace crossbred pigs, Res. Pig Breed., 3, 4-6, 2009.

Jeong, D. W., Choi, Y. M., Lee, S. H., Choe, J. H., Hong, K. C., Park, H. C., and Kim, B. C.: Correlations of trained panel sensory values of cooked pork with fatty acid composition, muscle fiber type, and pork quality characteristics in Berkshire pigs, Meat Science, 86, 607-615, https://doi.org/10.1016/j.meatsci.2010.04.011, 2010.

Juárez, M., Clemente, I., Polvillo, O., and Molina, A.: Meat quality of tenderloin from Iberian pigs as affected by breed strain and crossbreeding, Meat Science, 81, 573-579, https://doi.org/10.1016/j.meatsci.2008.10.016, 2009.

Parunović, N., Petrović, M., Matekalo-Sverak, V., Trbović, D., Mijatović, M., and Radović, Č.: Fatty acid profile and cholesterol content of $\mathrm{m}$. longissimus of free-range and conventionally reared Mangalitsa pigs, S. Afr. J. Anim. Sci., 42, 101-113, 2012.

Parunović, N., Petrović, M., Matekalo-Sverak, V., Radović, Č., and Stanišić, N.: Carcass properties, chemical content and fatty acid composition of the Musculus longissimus of different pig genotypes, S. Afr. J. Anim. Sci., 43, 123-136, https://doi.org/10.4314/sajas.v43i2.2, 2013.

Pârvu, M., Bogdan, A. T., Andronie, I. C., and Amfim, A.: Aspects of Energy Metabolism in Mangalitsa Pigsa Exposed at Thermic
Neutral Temeperature, Scient. Pap.: Anim. Sci. Biotechnol., 44, 180-182, 2011.

Pârvu, M., Bogdan, A. T., Andronie, I. C., Simion, V. E., and Amfim, A.: Influence of Cold Stress on the Chemical Composition of Carcass to Mangalica pigs, Scient. Pap.: Anim. Sci. Biotechnol. Anim. Husband., 45, 394-396, 2012.

Peinado, B., Poto, A., Gil, F., and López, G.: Characteristics of the carcass and meat of the Chato Murciano pigs, Livestrock Prod. Sci., 90, 285-292, https://doi.org/10.1016/j.livprodsci.2004.07.018, 2004.

Petrović, M., Wähner, M., Radović, Č., Radojović, D., Parunović, N., Savić, R., and Brkić, N.: Fatty acid profile of $m$. longissimus dorsi of Mangalitsa and Moravka pig breeds, Archiv Tierzucht, 57, 1-2, https://doi.org/10.7482/0003-9438-57-017, 2014.

PN-ISO 1444:2000: Meat and meat products. Determination of free fat content, Polish Committee for Standarization, Warsaw, 2000.

PN-75/A-04018: Produkty rolniczo-żywnościowe, Oznaczanie azotu metodą Kjeldahla i przeliczanie na białko, South African Journal of Animal Science, Poland, 1975.

Poto, A., Galián, M., and Peinado, B.: Chato Murciano pig and its crosses with Iberian and Large White pigs, reared outdoors. Comparative study of the carcass and meat characteristics, Livestock Sci., 11, 96-103, https://doi.org/10.1016/j.livsci.2006.12.005, 2007.

Raes, K., De Smet, S., and Demeyer, D.: Effect of doublemuscling in Belgian Blue young bulls on the instramuscular fatty acid composition with emphasis on conjugated linoleic acid and polyunsaturated fatty acids, Anim. Sci., 73, 253-260, https://doi.org/10.1017/S1357729800058227, 2001.

Ramírez, R. and Cava, R.: Carcass composition and meat quality of three different Iberian $\times$ Duroc genotype pigs, Meat Science, 75 , 388-396, https://doi.org/10.1016/j.meatsci.2006.08.003, 2007.

Renaudeau, D. and Mourot, J. A.: comparison of carcass and meat quality characteristics of Creole and Large White pigs slaughtered at $90 \mathrm{~kg} \mathrm{BW}$, Meat Science, 76, 165-171, https://doi.org/10.1016/j.meatsci.2006.10.024, 2007.

SAS Institute Inc.: SAS ${ }^{\circledR}$ 9.2, SAS Institute Inc., Cary, NC, 2012.

Serra, X., Gil, F., Pérez-Enciso, M., Oliver, M. A., Vázquez, J. M., Gispert, M., Díaz, I., Moreno, F., Latorre, R., and Noguera, J. L.: A comparison of carcass, meat quality and histochemical characteristics of Iberian (Guadyerbas line) and Landrace pigs, Livestock Prod. Sci., 56, 215-223, https://doi.org/10.1016/s03016226(98)00151-1, 1998.

Sirtori, F., Crovetti, A., Zilio, D. M., Pugliese, C., Acciaioli, A., Campodoni, G., Bozzi, R., and Franci, O.: Effect of sire breed and rearing system on growth, carcass composition and meat traits of Cinta Senese crossbred pigs, Ital. J. Anim. Sci., 10, 189194, https://doi.org/10.4081/ijas.2011.e47, 2011.

Stanišić, N., Radović, Č., Stajić, S., Živković, D., and Tomašević, I.: Physicochemical properties of meat from Mangalitsa pig breed, Meso, 17, 50-53, 2015.

Stanišić, N., Parunović, N., Stajić, S., Petrović, M., Radović, Č., Živković, D., and Petričević, M.: Differences in meat colour between free-range Swallow Belly Mangalitsa and commercially reared Swedish Landrace pigs during 6 days of vacuum storage, Arch. Anim. Breed., 59, 159-166, https://doi.org/10.5194/aab59-159-2016, 2016.

Szabó, A., Horn, P., Romvári, R., Házas, Z. and Fébel, H.: Comparison of Mangalica and Hungarian Large White pigs at identical 
bodyweight: 2 . Fatty acid regiodistribution analysis of the triacylglycerols, Archiv Tierzucht, 53, 147-161, 2010.

Szulc, K., Skrzyppczak, E., Buczyński, J. T., Stanislawski, D., Jankowska-Makosa, A., and Knecht, D.: Evaluation of fattening and slaughter performance and determination of meat quality in Złotnicka Spotted pig and their crosses with the Duroc breed, Czech J. Anim. Sci., 57, 95-107, 2012a.

Szulc, K., Lisiak, D., Grzeoekowiak, E., and Nowaczewski, S.: The influence of cross-breeding Zlotnicka Spotted native breed sos with boars of Duroc (D) and Polish Large White (PLW) Leeds on meat quality, Afr. J. Biotechnol., 11, 4471-4477, https://doi.org/10.5897/AJB11.3504, 2012b.

Tomović, V. M., Šević, R., Jokanović, M., Šojić, B., Škaljac, S., Tasić, T., Ikonić, P., Polak, M. L., Polak, T., and Demšar, L.: Quality traits of longissimus lumborum muscle from White Mangalica, Duroc $\times$ White Mangalica and Large White pigs reared under intensive conditions and slaughtered at $150 \mathrm{~kg}$ live weight: a comparative study, Arch. Anim. Breed, 59, 401-415, https://doi.org/10.5194/aab-59-401-2016, 2016.
Tyra, M. and Žak, G.: Characteristics of the polish breeding population of pigs in terms of intramuscular fat (IMF) content of m. longissimus dorsi, Ann. Anim. Sci., 10, 241-248, 2010.

Wood, J. D., Richardson, R. I., Nute, G. R., Fisher, A. V., Campo, M. M., Kasapidou, E., Sheard, P. R., and Enser, M.: Effects of fatty acids on meat quality: a review, Meat Science, 66, 21-32, https://doi.org/10.1016/S0309-1740(03)00022-6, 2003.

Wood, J. D., Enser, M., Fisher, A. V., Nute, G. R., Sheard, P. R., Richardson, R. I., Hughes, S. I., and Whittingtion, F. M.: Fat deposition, fatty acid composition and meat quality: A review, Meat Science, 78, 343-358, https://doi.org/10.1016/j.meatsci.2007.07.019, 2008.

Wojtyšiak, D. and Poltowicz, K.: Carcass quality, physicochemical paramterers, muscle fibres traits and myosin heavy chain composition of $\mathrm{m}$. longissimus lumborum from Pulawska and Polish Large White pigs, Meat Science, 97, 395-403, https://doi.org/10.1016/j.meatsci.2014.03.006, 2014. 